\title{
Evaluation of the storage quality characteristics of 'Tteokbokki' sauce in the presence of preservatives and following heat sterilization
}

\author{
Ji-Young Choi ${ }^{1}$, Jiyoon $\mathrm{Kim}^{1}$, Jungsoo Kim ${ }^{1}$, Saeul Jeong ${ }^{1}$, Kwang-Deog Moon ${ }^{1,2 *}$ \\ ${ }^{1}$ School of Food Science and Technology, Kyungpook National University, Daegu 41566, Korea \\ ${ }^{2}$ Food and Bio-industry Research Institute, Kyungpook National University, Daegu 41566, Korea
}

\section{보존제 첨가 및 가열 살균에 따른 떡볶이 소스의 저장 중 품질 특성 평가}

\author{
최지영 ${ }^{1} \cdot$ 김지윤 $^{1} \cdot$ 김정수 $^{1} \cdot$ 정 새울 ${ }^{1} \cdot$ 문광덕 ${ }^{1,2 *}$ \\ ${ }^{1}$ 경북대학교 식품공학부 식품생물공학전공, ${ }^{2}$ 경북대학교 식품생물산업연구소
}

\begin{abstract}
When 'Tteokbokki' sauce is distributed and stored in the summer, the number of microbial generations increases rapidly, and the sauce packaging swells or breaks due to gas generation. In this study, the use of preservatives and heat sterilization was examined to determine their effects on red pepper paste-based 'Tteokbokki' sauce. When preservative addition and heat sterilization were combined, $\mathrm{CO}_{2}$ gas generation was increased, while the use of either preservatives alone or heat sterilization alone reduced gas generation compared to the control. Microbial load was significantly lower in the combined sample, and heat sterilization treatment was found to exhibit only a slight sterilization effect. However, no bactericidal effect was observed only in the presence of preservatives. Similar sensory evaluation results were obtained for all treated samples. These results therefore indicated that the sterilization effect of heat sterilization in 'Tteokbokki' sauce was maximized when combined with preservatives, with no significant alteration in the quality characteristics being detected. However, in the case of the combined treatment, a heat stable preservative should be used to prevent the generation of carbon dioxide gas.
\end{abstract}

Key words : sauce, heat sterilization, preservative, $\mathrm{CO}_{2}$ gas, microorganism

서 론

떡볶이는 쌀을 원료한 가래떡을 주재료로 하고, 간장, 된장과 더불어 우리나라 3 대 장류 중 하나인 고추장을 양념으로 하는 음식이다(Kim 등, 2011). 떡볶이 소스의 주재료인 고추장은 숙성 과정 중 amylase, protease 등 효소 작용으로 단맛, 구수한 맛, 매운맛, 짠맛 등이 조화를 이루 어 독특한 풍미를 형성하는 전통발효식품으로서, 많은 종 류의 세균이나 곰팡이류가 서식하고 있으며, 이들의 발효 작용으로 각종 향미와 색택이 개량된다(Chun 등, 1995).
장류를 이용한 소스 상품 연구와 관련하여 지금까지는 주로 고추장을 이용한 소스 제품 개발에 관한 연구가 주를 이루고 있으며(Hong 등, 2008), 이러한 소스 상품 개발에 있어서 관련 미생물의 제어는 매우 중요한 과제로 부각되 고 있다(Lee 등, 2012a). 이러한 떡볶이 소스는 특히 여름철 생산, 유통, 저장되는 경우에 미생물 발생 수가 급증하게 되며, 소스 용기가 부풀어 오르고 심한 경우 용기가 파손 되어 내용물이 흘러나오게 되는 문제가 발생한다. Lee 등 (1997)은 재래식 고추장의 산업화에서 문제가 되는 것 중 하나는 제품 수송과 유통과정에서 가스가 발생하여 팽창

*Corresponding author. E-mail : kdmoon@knu.ac.kr, Phone :+82-53-950-5773, Fax :+82-53-950-6772

Received 18 March 2020; Revised 08 April 2020; Accepted 18 April 2020.

Copyright (C) The Korean Society of Food Preservation.

This is an Open Access article distributed under the terms of the Creative Commons Attribution Non-Commercial License (http://creativecommons.org/licenses/by-nc/4.0) which permits unrestricted non-commercial use, distribution, and reproduction in any medium, provided the original work is properly cited. 
하므로 국내 소비는 물론 수출에 큰 장애가 되고 있다고 언급하였다. 이러한 문제로 여름이나 높은 온도의 공간에 서 유통하는 것이 어려워지게 되면서 미생물 증식을 억제 시킬 수 있는 방안 제시가 요구되고 있는 실정이다. 미생 물 증식을 억제시킬 수 있는 여러 가지 방법 중 가장 쉽게 적용할 수 있는 것은 보존료 처리에 의한 것으로, 미생물 오염으로 인한 식품의 부패와 변질을 예방하는데 널리 사용된다(Li XQ 등, 2008). 보존제를 첨가하는 방법 외에 다양한 물리적인 살균 방법이 있는데, 고추장을 기반으로 한 소스의 살균 연구 사례로는 감마선 조사(Kim 등, 2001), 열과 초고압처리(Lim 등, 2001), 연속 옴가열 처리(Choi 등, 2015) 등이 있다. 그러나 고추장, 간장 등이 포함된 소스에는 유익균뿐만 아니라, 식중독 유발세균의 검출빈 도가 높아, 장류를 이용한 소스 상품 제조 시 품질변화를 최소화한 효과적인 살균방법이 필요하다(Lee 등, 2012a). 본 연구에서는 떡볶이 소스의 품질 보존을 위해 천연 보존 제인 마늘 복합 추출물, 비타민 $\mathrm{B}_{1}$ 라우릴황산염(thiamine dilaurylsulfate)과 인공 보존제인 파라옥시안식향산에틸 (ethyl p-hydroxybenzoate)을 첨가하였으며, 가열 살균을 살 균법으로 사용하였다. 따라서 본 연구에서는 고온환경에 서 떡볶이 소스의 미생물 증식으로 인한 가스발생, 품질저 하 등을 최소화할 목적으로 천연보존제 처리 및 가열 살균 의 효과를 비교 분석하였고, 품질 보존을 위한 적합한 처 리 방법을 확인하였다.

\section{재료 및 방법}

\section{실험재료}

떡볶이 소스의 주요 원재료는 고추장(물엿, 소맥분, 정 제수, 혼합양념, 밀쌀, L-글루탐산나트륨, 종국), 물엿, 정 백당, 과당, 포도당, 레몬식초, 주정, 효모추출물, 고춧가 루, 마늘분말, 케찹, 변성전분 등이 포함되었다. 보존료 및 살균 처리 유무에 따라 실험군을 각각 어떠한 처리도 하지 않은 소스를 CONT, 가열 살균 후 보존제를 첨가, 혼합한 소스를 $\mathrm{BOSO}$, 보존제만 첨가한 소스를 $\mathrm{BO}$, 가열 살균만 한 소스를 $\mathrm{SO}$ 로 명명하였다. 이때 사용된 보존제 는 천연 보존료인 비타민 $\mathrm{B}_{1}$ 라우릴황산염(thiamine dilaurylsulfate)과 마늘복합추출물, 인공 보존제인 파라옥 시안식향산에틸(ethyl p-hydroxybenzoate)을 혼합하여 사 용하였다. 떡볶이 소스의 살균 처리는 $90^{\circ} \mathrm{C}$ 로 가열시켜 10 분 교반 후 냉각수로 냉각시키는 방식으로 진행하였다. 이때 소스에 포함된 변성 전분이 $90^{\circ} \mathrm{C}$ 가 되어야 소스로서 의 적절한 점성을 띠므로, 상업적인 살균처리 방법과는 다른 온도로 진행되었다. 변성전분은 다른 전분들보다 제 품을 오래 보관할 시 노화 현상이 적게 발생하기 때문에 사용하였다. 살균 및 보존제 첨가를 마친 각각의 소스는
Polyethylene terephthalate(PETE) 용기에 약 $100 \mathrm{~mL}$ 씩 담아 밀폐하였으며, 포장 후 별도의 살균 공정은 없었다. $35^{\circ} \mathrm{C}$ 에 8 주간 저장하면서 2 주 간격으로 그룹당 3 병씩 꺼내어 품질 특성 분석을 수행하였다.

\section{$\mathrm{CO}_{2}$ 가스 분석}

소스 용기 변형의 원인이 되는 $\mathrm{CO}_{2}$ 가스 분석은 그룹당 꺼내어진 3 개의 밀폐된 용기 head space 부분에 needle을 각각 한번씩 삽입하여 gas analyzer(DualTrak oxygen/carbon dioxide analyzer 902D, Quantek Instruments, Northboro, $\mathrm{MA}, \mathrm{USA}$ )를 통해 소스에서 발생된 $\mathrm{CO}_{2}$ 양을 분석하였다. 따라서 그룹당 3 반복 측정한 것이며, 결과 값의 단위는 $\%$ 로 나타내었다.

\section{$\mathrm{pH}$, 가용성 고형분 및 염도 측정}

$\mathrm{pH}$, 가용성 고형분 및 염도는 별도의 추출 과정 없이 떡볶이 소스의 원액으로 측정하였다. $\mathrm{pH}$ 는 $\mathrm{pH} \operatorname{meter}(\mathrm{pH}$ 510 benchtop meter, Oakton Instruments, Vernon Hills, IL, $\mathrm{USA}$ 로 측정하였으며, 가용성 고형분은 굴절 당도계(N2, Atago Co., Tokyo, Japan)에 소스 원액을 한방울 떨어트려 측정하고 ${ }^{\circ} \mathrm{Brix}$ 로 나타내었다. 염도는 소스 원액에 염도계 (salinometer salt-free 2500, CAS, Suwon, Korea) 측정 부위 를 꽂아 측정하였고, \%로 나타내었다.

\section{환원당 및 유리당 함량 분석}

떡볶이 소스의 단맛, 풍미를 결정짓는 환원당 및 유리당 함량을 분석하였다. 시료 $5 \mathrm{~g}$ 에 증류수 $45 \mathrm{~mL}$ 를 가하고, $50^{\circ} \mathrm{C}$, 출력 $70 \%$ 로 설정된 Ultrasonic cleaner(DH.WUC.D22H, Daihan-sci, Wonju, Korea)에서 1시간 동안 초음파 추출 후, Whatman No. 4로 여과하였다. 여액을 $0.45 \mu \mathrm{m}$ 실린지 필터로 다시 여과한 것을 환원당과 유리당 함량 분석의 시액으로 사용하였다. 환원 당은 Ghose(1987)의 DNS법을 변형하여 측정하였다. 시액을 희석 후, DNS 시약을 넣고 10 분간 방치 후 UV-Vis spectrophotometer(Evolution 201, Thermo Fisher Scientific InC, Madison, WI, USA)를 사용하 여 $540 \mathrm{~nm}$ 에서 흡광도를 측정하였으며, glucose(SigmaAldrich Co., St. Louis, MO, USA)를 표준물질로 나타냈다.

유리당은 high performance liquid chromatography(HPLC, Alliance, Waters Co., Milford, MA, USA)으로 정량하였으 며, mobile phase는 $0.01 \mathrm{M} \mathrm{Ca-EDTA}\left(50 \mathrm{mg} / 1 \mathrm{~L}\right.$ d. $\left.\mathrm{H}_{2} \mathrm{O}\right)$, column은 Sugar-Pak I column $(\varnothing 6.5 \times 300 \mathrm{~mm}$, Waters Co.) 을 사용하였다.

\section{색도 측정}

소스의 외관을 평가할 수 있는 색도는 백색판 $\left(\mathrm{L}^{*}=97.79\right.$, $a^{*}=-0.38, b^{*}=2.05$ )으로 보정된 colorimeter(CR-400, Konica 
Minolta Co., Osaka, Japan)로 측정하였으며, 명도 $\left(\mathrm{L}^{*}=\right.$ lightness $)$, 적색도( $\left.\mathrm{a}^{*}=\mathrm{redness}\right)$, 황색도( $\mathrm{b}^{*}=$ yellowness $)$ 로 나 타냈다. Total color difference $(\Delta \mathrm{E})$ 는 다음 식에 의해 계산 하였다.

$$
\Delta \mathrm{E}=\left[\left(\mathrm{L}^{*}-\mathrm{L}_{0}{ }^{*}\right)^{2}+\left(\mathrm{a}^{*}-\mathrm{a}_{0}{ }^{*}\right)^{2}+\left(\mathrm{b}^{*}-\mathrm{b}_{0}{ }^{*}\right)^{2}\right]^{1 / 2}
$$

$\mathrm{L}_{0}^{*}$ : initial lightness value of the source

$\mathrm{a}_{0}{ }^{*}$ : initial redness value of the source

$\mathrm{b}_{0}{ }^{*}$ : initial yellowness value of the source

\section{미생물 분석}

소스 용기에 가스를 발생시키는 주 요인인 미생물 발생 정도를 확인하였다. 미생물 분석은 일반 호기성 세균과 곰 팡이 및 효모 수를 분석하였다. 시료 $5 \mathrm{~g}$ 을 취하여 peptone 수로 희석한 것을 분주하였으며, 일반 세균은 plate count agar(PCA, Difco, Franklin Lakes, NJ, USA)에서 $35 \pm 1{ }^{\circ} \mathrm{C}$ 에 48시간, 곰팡이 및 효모는 potato dextrose agar(PDA, Difco, Franklin Lakes, NJ, USA)에서 $25 \pm 1{ }^{\circ} \mathrm{C}$ 에서 5일간 배양하였 다. 배양 후 colony를 계수하여 $\log \mathrm{CFU} / \mathrm{g}$ 단위로 나타내었 다.

\section{관능검사}

관능검사는 훈련된 경북대학교 대학원생 10 명을 대상 으로 실시하였으며, 색, 달콤한 향, 시큼한 향, 매콤한 향, 점도, 종합적 기호도 항목으로 나누어 7점법을 기준으로 절대평가 하도록 하였다. 본 관능검사는 경북대학교 생명 윤리심의위원회에서 면제 승인을 받고 안전하게 진행하 였다.

\section{결과 및 고찰}

\section{$\mathrm{CO}_{2}$ 가스 발생}

$\mathrm{CO}_{2}$ 발생량은 소스 저장 중 품질을 저하시키는 요인이 며(Kim과 Kwon, 2001), 과량 발생 시 소스 포장에서 압력 발생이나 부피팽창을 유발하기 때문에 $(\operatorname{Kim}$ 등, 2000) 유 통 시 문제를 발생할 수 있다. 떡볶이 소스의 저장 중 $\mathrm{CO}_{2}$ 가스 측정 결과는 Table 1에 나타내었다. 장류에서의 $\mathrm{CO}_{2}$ 생산은 주로 Zygosaccharomyces rouxii, Saccharomyces cerevisiae, Candida versatilis, C. etchellsii와 같은 내염성 효모의 성장에 기인하며, 숙성 후기에는 감소하나 배합이 나 충전, 포장 공정 등 새로운 환경에서 다시 번식하는 것으로 보고되어 $(\mathrm{Kim}$ 등, 2000$)$, 시료 초기 $\mathrm{CO}_{2}$ 함량이 차이가 있는 것으로 보인다. 저장 기간에 따른 $\mathrm{CO}_{2}$ 발생량 은 모든 시료에서 유의적으로 증가하는 경향을 보였다. 저장 중 $\mathrm{CO}_{2}$ 발생량은 $\mathrm{CONT}$ 에서 $1.67-4.97 \%$ 로 높은 경 향으로 나타났고, $\mathrm{BOSO}$ 는 $1.37-5.07 \%$ 로 $\mathrm{CONT}$ 와 비슷 한 경향을 보였다. $\mathrm{BO}$ 와 $\mathrm{SO}$ 는 전 기간동안 비교적 낮은 $\mathrm{CO}_{2}$ 발생량을 나타냈다. 고추장의 가스 발생은 주로 효모 에 의해서 일어나기 때문에 $(\operatorname{Kim}$ 등, 1998) 보존료 또는 살균 처리를 했을 때, $\mathrm{CO}_{2}$ 발생량이 가장 적었으며, 반면에 두 가지 처리를 병용했을 시 무처리구인 $\mathrm{CONT}$ 와 차이가 나타나지 않았다. 보존제로 사용된 파라옥시안식향산에틸 은 공기 중 안정하며 온도변화에 강하고, 가열을 하여도 가수분해가 일어나지 않는다. 또한, 비타민 $\mathrm{B}_{1}$ 라우릴황산 염 역시 열에 대한 안정성이 큰 보존제이기 때문에 가열에 의해 보존제 성질이 변화된 것은 아닌 것으로 보인다 $(\mathrm{Kim}$, 2005). 반면에 마늘 복합 추출물에는 알리신 $\left(\mathrm{C}_{6} \mathrm{H}_{10} \mathrm{~S}_{2} \mathrm{O}\right)$ 외 에 다양한 유황화합물질이 들어 있으며(Choi 등, 2007), 가열살균 처리됨에 따라 소스에서 많은 부분을 차지하는 당성분과 반응하여 $\mathrm{CO}_{2}$ 가스를 발생시켰을 것으로 사료 된다(Song 등, 2008). 마늘 조직이 파괴되면서 발생한 불안 정한 allicin은 분해되자마자 저급 황화합물 및 carbonyl

Table 1. Changes in $\mathrm{CO}_{2}$ generation of 'Tteokbokki' sauce during storage

\begin{tabular}{|c|c|c|c|c|c|}
\hline & \multirow{2}{*}{$\begin{array}{l}\text { Storage period } \\
\text { (week) }\end{array}$} & \multicolumn{4}{|c|}{ Sample ${ }^{1)}$} \\
\hline & & BOSO & $\mathrm{BO}$ & SO & CONT \\
\hline \multirow{5}{*}{$\mathrm{CO}_{2}(\%)$} & 0 & $1.37 \pm 0.21^{2) \mathrm{bA} 3)}$ & $0.43 \pm 0.23^{\mathrm{aA}}$ & $0.47 \pm 0.21^{\mathrm{aA}}$ & $1.67 \pm 0.65^{\mathrm{bA}}$ \\
\hline & 2 & $2.47 \pm 0.32^{\mathrm{abB}}$ & $2.03 \pm 0.21^{\mathrm{aB}}$ & $2.57 \pm 0.35^{\mathrm{abB}}$ & $3.10 \pm 0.79^{\mathrm{bB}}$ \\
\hline & 4 & $3.63 \pm 0.21^{\mathrm{cC}}$ & $3.00 \pm 0.40^{\mathrm{bC}}$ & $2.50 \pm 0.17^{\mathrm{aB}}$ & $3.50 \pm 0.17^{\mathrm{cB}}$ \\
\hline & 6 & $4.10 \pm 0.40^{\mathrm{abC}}$ & $3.33 \pm 0.35^{\mathrm{aC}}$ & $3.47 \pm 0.21^{\mathrm{aC}}$ & $4.73 \pm 0.57^{\mathrm{bC}}$ \\
\hline & 8 & $5.07 \pm 0.23^{\mathrm{bD}}$ & $3.93 \pm 0.40^{\mathrm{aD}}$ & $3.83 \pm 0.23^{\mathrm{aC}}$ & $4.97 \pm 0.21^{\mathrm{bC}}$ \\
\hline
\end{tabular}

${ }^{1)} \mathrm{BOSO}$, sauce with added preservatives and heated sterilization; BO, sauce with added preservatives; SO, heat sterilized sauce; CONT, unprocessed sauce.

${ }^{2)}$ Values are mean \pm SD of triplicate determinations.

${ }^{3)}$ Values followed by different uppercase letters $\left({ }^{\mathrm{a}-\mathrm{c}}\right)$ within a row and by different uppercase letters $\left({ }^{\mathrm{A}-\mathrm{D}}\right)$ within a column are significantly different at $\mathrm{p}<0.05$ based on Duncan's multiple range test. 
화합물을 만들고, 온도나 $\mathrm{pH}$ 에 따라 분해 속도와 분해물 질이 다르게 나타난다. Kim과 Yang(1998)은 생마늘은 13 가지, 구운마늘은 11 가지의 휘발성 유기화합물을 발생시 키며, 대부분 sulfide 결합을 나타내고 있다고 언급해, 마늘 이 가열처리되어도 가스를 발생시킬 수 있다고 판단되었 다. Kim 등(2002)은 마늘을 첨가하지 않은 김치는 탄산가 스 방출량이 가장 낮아 용기 안 압력이 낮았다고 밝혔다. 또한 마늘추출물이 호기성 세균의 생육은 억제하지만 젖 산균의 생육은 촉진시키기 때문에 소스 자체의 살균작용 은 할수 있지만 가스발생은 오히려 촉진할 수 있다(Cho와 Jhon, 1988). Kim과 Kwon(2001)의 연구에서는 마늘이 첨 가된 고추장은 $30^{\circ} \mathrm{C}$ 에서 저장 중 $\alpha$-amylase, $\beta$-amylase, acidic protease, neutral protease의 활성이 다른 고추장에 비해 높게 나타나고, 탄산가스와 알코올의 함량을 증가시 킨다고 하였다(Mantis 등, 1978). 따라서 마늘 복합 추출물 이 포함된 보존제와 가열살균 처리를 병용하는 것은 떡볶 이 소스의 $\mathrm{CO}_{2}$ 가스 발생을 억제하는 것에는 큰 효과가 없는 것을 확인되었으나, 보존제와 살균처리를 각각 적용 하는 것이 $\mathrm{CO}_{2}$ 발생을 줄이는 데 더욱 적합할 것으로 보인 다. 또한, 소스의 가스 발생을 유발하는 원인이 마늘 복합 추출물인 것인지는 추가적인 연구를 통해 사용 여부를 결정할 필요가 있다.

\section{$\mathrm{pH}$, 가용성 고형분 및 염도}

소스의 $\mathrm{pH}$ 와 가용성 고형분 및 염도 변화는 Table 2에 나타냈다. 염도의 경우, 저장 기간 동안 유의적인 증가는 나타나지 않았고, 전처리 방법에 의한 차이도 크지 않았 다. 가용성 고형분의 경우, 전체적으로 시간이 지남에 따 라 증가하는 양상을 보여, Gwon(1999)과 Park(2015)의 연 구결과와 유사하였다. 이는 저장기간 동안 발효가 진행됨 에 따라 효소의 활성으로 탄수화물이 당분으로 전환되는 당화작용이 일어난 것에 기인된 것으로 보인다(Lee 등, 2012b). BO는 전 기간 동안 $49.43-50.20{ }^{\circ} \mathrm{Brix}$ 로 가장 낮 은 가용성 고형분 함량을 유지했으며, $\mathrm{BOSO}$ 가 50.57 $51.53{ }^{\circ} \mathrm{Brix}$ 로 가장 높은 경향을 보였다. 비가열 살균군보 다 가열 살균군에서 비교적 높은 값을 나타내는 것을 확인 하였으며, 이는 가열처리로 인해 소스의 재료로 들어간 양파나 마늘의 최루성분이 분해되면서 생성되는 단맛성 분의 생성에 기인한 것으로 사료된다(Lee 등, 2013). $\mathrm{pH}$ 의 경우, 저장 2 주 차까지 시료 간의 유의적인 차이는 없었고, $\mathrm{BOSO}$ 가 4주 차, 8 주 차에 비교적 약간 높은 것을 볼 수 있다. 전체적으로 감소하는 양상을 보였으며, 이는 소스의 미생물 대사에 의한 유기산 생성으로 $\mathrm{pH}$ 는 감소하고 적정 산도는 감소하기 때문이다(Kim 등, 1993; Lee 등, 1997). 전반적으로 소스의 염도, 가용성 고형분 함량, $\mathrm{pH}$ 는 전처

Table 2. Changes in salinity, soluble solids, and pH of 'Tteokbokki' sauce during storage

\begin{tabular}{|c|c|c|c|c|c|c|}
\hline & \multirow{2}{*}{ Sample ${ }^{1)}$} & \multicolumn{5}{|c|}{ Storage period (week) } \\
\hline & & 0 & 2 & 4 & 6 & 8 \\
\hline \multirow{4}{*}{$\begin{array}{l}\text { Salinity } \\
(\%)\end{array}$} & BOSO & $0.32 \pm 0.03^{2) \mathrm{aAB} 3)}$ & $0.34 \pm 0.04^{\mathrm{aB}}$ & $0.30 \pm 0.02^{\mathrm{aAB}}$ & $0.33 \pm 0.01^{\mathrm{bB}}$ & $0.28 \pm 0.02^{\mathrm{aA}}$ \\
\hline & $\mathrm{BO}$ & $0.33 \pm 0.03^{\mathrm{aAB}}$ & $0.34 \pm 0.05^{\mathrm{aB}}$ & $0.35 \pm 0.01^{\mathrm{bB}}$ & $0.37 \pm 0.01^{\mathrm{cB}}$ & $0.28 \pm 0.02^{\mathrm{aA}}$ \\
\hline & SO & $0.31 \pm 0.04^{\mathrm{aB}}$ & $0.29 \pm 0.01^{\mathrm{aAB}}$ & $0.33 \pm 0.01^{\mathrm{abB}}$ & $0.32 \pm 0.01^{\mathrm{bB}}$ & $0.26 \pm 0.02^{\mathrm{aA}}$ \\
\hline & CONT & $0.39 \pm 0.01^{\mathrm{bC}}$ & $0.34 \pm 0.04^{\mathrm{aABC}}$ & $0.31 \pm 0.02^{\mathrm{aAB}}$ & $0.29 \pm 0.00^{\mathrm{aA}}$ & $0.36 \pm 0.05^{\mathrm{bBC}}$ \\
\hline \multirow{4}{*}{$\begin{array}{l}\text { Soluble } \\
\text { Solids } \\
\text { ('Brix) }\end{array}$} & BOSO & $50.57 \pm 0.06^{\mathrm{bA}}$ & $51.47 \pm 0.23^{\mathrm{cB}}$ & $51.40 \pm 0.20^{\mathrm{cB}}$ & $51.53 \pm 0.50^{\mathrm{cB}}$ & $51.33 \pm 0.23^{\mathrm{cB}}$ \\
\hline & $\mathrm{BO}$ & $49.43 \pm 0.25^{\mathrm{aA}}$ & $50.13 \pm 0.42^{\mathrm{aB}}$ & $50.20 \pm 0.20^{\mathrm{aB}}$ & $49.87 \pm 0.12^{\mathrm{aAB}}$ & $49.93 \pm 0.23^{\mathrm{aB}}$ \\
\hline & $\mathrm{SO}$ & $50.97 \pm 0.47^{\mathrm{bA}}$ & $51.27 \pm 0.31^{\mathrm{bcA}}$ & $51.13 \pm 0.12^{\mathrm{bA}}$ & $50.93 \pm 0.12^{\mathrm{bA}}$ & $51.07 \pm 0.12^{\mathrm{bcA}}$ \\
\hline & CONT & $49.90 \pm 0.10^{\mathrm{aA}}$ & $50.67 \pm 0.31^{\mathrm{abBC}}$ & $51.00 \pm 0.00^{\mathrm{bD}}$ & $50.53 \pm 0.12^{\mathrm{bB}}$ & $50.87 \pm 0.12^{\mathrm{bCD}}$ \\
\hline \multirow{4}{*}{$\mathrm{pH}$} & BOSO & $4.70 \pm 0.02^{\mathrm{aC}}$ & $4.64 \pm 0.02^{\mathrm{aB}}$ & $4.52 \pm 0.01^{\mathrm{aA}}$ & $4.56 \pm 0.02^{\mathrm{aA}}$ & $4.62 \pm 0.03^{\mathrm{aB}}$ \\
\hline & $\mathrm{BO}$ & $4.69 \pm 0.01^{\mathrm{aC}}$ & $4.62 \pm 0.02^{\mathrm{aB}}$ & $4.57 \pm 0.02^{\mathrm{bcA}}$ & $4.59 \pm 0.03^{\mathrm{aA}}$ & $4.66 \pm 0.01^{\mathrm{bC}}$ \\
\hline & $\mathrm{SO}$ & $4.69 \pm 0.02^{\mathrm{aD}}$ & $4.65 \pm 0.02^{\mathrm{aC}}$ & $4.59 \pm 0.02^{\mathrm{cB}}$ & $4.56 \pm 0.01^{\mathrm{aA}}$ & $4.63 \pm 0.01^{\mathrm{abC}}$ \\
\hline & CONT & $4.68 \pm 0.02^{\mathrm{aD}}$ & $4.63 \pm 0.02^{\mathrm{aC}}$ & $4.55 \pm 0.01^{\mathrm{bA}}$ & $4.59 \pm 0.02^{\mathrm{aB}}$ & $4.64 \pm 0.01^{\mathrm{abC}}$ \\
\hline
\end{tabular}

${ }^{1)} \mathrm{BOSO}$, sauce with added preservatives and heated sterilization; BO, sauce with added preservatives; SO, heat sterilized sauce; CONT, unprocessed sauce.

${ }^{2)}$ Values are mean \pm SD of triplicate determinations.

${ }^{3)}$ Values followed by different uppercase letters $\left({ }^{\mathrm{a}-\mathrm{c}}\right)$ within a row and by different uppercase letters $\left({ }^{\mathrm{A}-\mathrm{D}}\right)$ within a column are significantly different at $p<0.05$ based on Duncan's multiple range test. 
리에 따른 차이는 크지 않았다.

\section{환원당 및 유리당 함량}

고추장에 있어서 단맛은 glucose, fructose, maltose 등의 당류로부터 기인되며, 이러한 당류의 전체적인 함량을 측 정하는데 신속한 방법으로 환원당을 측정하는 것은 고추 장 떡볶이 소스의 품질 특성을 파악하는데 편리하다(Kim, 1993). 저장 중 고추장을 기반으로 한 떡볶이 소스의 환원 당 및 유리당 함량은 Table 3에 나타냈다. 보존제와 살균 처리 유무와 상관없이 저장 0 주에 가장 많은 환원당 함량 을 나타냈으며, 4주까지 낮아지는 추세를 보이다가 6 주 이후로 높아지는 경향성을 나타냈다. 이러한 경향성은 이 전 연구 $(\mathrm{Kim}$ 등, 2002)와 유사하며, 특히 저장기간이 길어 짐에 따라 환원당 함량이 높아지는 것은 $\beta$-amylase 활성이 높아지기 때문으로 사료된다(Kim과 Kwon, 2001; Kang과 Song, 2006). 저장 4, 6, 8주 차에는 $\mathrm{BOSO}$ 의 환원당이 유의 적으로 낮은 값을 나타낸다. 곰팡이 및 효모 실험 결과와
비교하였을 때, 다른 시료에 비해 BOSO가 효모 수가 가장 낮았으며, 그에 따라 amylase 분비 및 활성이 낮아 환원당 함량이 낮은 것으로 사료된다(Kim과 Kwon, 2001; Kang과 Song, 2006).

모든 시료의 유리당의 함량은 sucrose, glucose, fructose 순으로 검출되었다. 가장 많이 검출된 sucrose의 경우 떡볶 이 양념 제조 시 사용된 감미료(설탕, 물엿 등)에서 유래된 것으로 보이며, fructose는 고추장에서 유래된 것으로 보인 다. 환원당 실험 결과에서 모든 시료에서 환원당 함량이 감소하는 경향을 보였는데, 이와 마찬가지로 저장기간 동 안 sucrose는 감소하고 glucose와 fructose는 증가하는 경향 을 확인할 수 있었다. 이것은 양념의 성분들이 효소작용이 나 미생물의 작용에 의해 단당류인 fructose로 분해된 것으 로 판단할 수 있다(Kwon, 1999). 또한, 유리당 함량은 열처 리 과정에서 sucrose가 분해되어 감소하나, 그 분해산물인 glucose와 fructose는 증가하였다는 $\operatorname{Kim}(2004)$ 의 연구 결 과를 바탕으로, $\mathrm{SO}$ 처리구가 이와 유사한 경향을 보이는

Table 3. Changes in reducing sugar content and free sugar content of 'Tteokbokki' sauce during storage

\begin{tabular}{|c|c|c|c|c|c|c|c|}
\hline & & \multirow{2}{*}{ Sample ${ }^{1)}$} & \multicolumn{5}{|c|}{ Storage period (week) } \\
\hline & & & 0 & 2 & 4 & 6 & 8 \\
\hline \multirow{4}{*}{\multicolumn{2}{|c|}{$\begin{array}{c}\text { Reducing } \\
\text { sugar } \\
\text { (glucose g/L) }\end{array}$}} & BOSO & $\left.21,136.78 \pm 536.80^{2) a \mathrm{aD}}\right)$ & $18,932.38 \pm 701.21^{\mathrm{aC}}$ & $16,006.67 \pm 373.84^{\mathrm{abA}}$ & $16,954 \cdot 17 \pm 237.61^{\mathrm{aB}}$ & $18,405.56 \pm 221.94^{\mathrm{aC}}$ \\
\hline & & $\mathrm{BO}$ & $20,734.48 \pm 1,908.43^{\mathrm{aC}}$ & $18,970.48 \pm 528.64^{\mathrm{aB}}$ & $15,806.67 \pm 270.35^{\mathrm{abA}}$ & $17,454.17 \pm 312.58^{\mathrm{bcAB}}$ & $19,050.00 \pm 185.59^{\mathrm{bB}}$ \\
\hline & & SO & $20,929.89 \pm 1,357.73^{\mathrm{aD}}$ & $19,475.24 \pm 190.24^{\mathrm{aC}}$ & $15,717.78 \pm 411.56^{\mathrm{aA}}$ & $17,062.50 \pm 175.00^{\mathrm{abB}}$ & $19,238.89 \pm 298.76^{\mathrm{bC}}$ \\
\hline & & CONT & $20,205.75 \pm 1,775.22^{\mathrm{aC}}$ & $19,018.1 \pm 128.84^{\mathrm{aBC}}$ & $16,369 \cdot 63 \pm 78.04^{\mathrm{bA}}$ & $17,754.17 \pm 202.07^{\mathrm{cAB}}$ & $19,038.89 \pm 101.84^{\mathrm{bBC}}$ \\
\hline \multirow{12}{*}{$\begin{array}{c}\text { Free } \\
\left.\text { sugar }^{4}\right) \\
(\mathrm{mg} / \mathrm{mL})\end{array}$} & \multirow{4}{*}{$\mathrm{Su}$} & BOSO & $251.90 \pm 2.84^{\mathrm{aBC}}$ & $241.05 \pm 9.11^{\mathrm{aA}}$ & $253.45 \pm 1.26^{\mathrm{aC}}$ & $246.15 \pm 5.69^{\mathrm{aABC}}$ & $242.84 \pm 3.88^{\mathrm{aAB}}$ \\
\hline & & $\mathrm{BO}$ & $255.83 \pm 5.76^{\mathrm{aB}}$ & $247.19 \pm 2.11^{\mathrm{abA}}$ & $246.01 \pm 3.87^{\mathrm{aA}}$ & $241.85 \pm 7.51^{\mathrm{aA}}$ & $243.81 \pm 0.87^{\mathrm{abA}}$ \\
\hline & & $\mathrm{SO}$ & $256.66 \pm 5.28^{\mathrm{aB}}$ & $256.77 \pm 4.22^{\mathrm{bB}}$ & $249.86 \pm 5.72^{\mathrm{aB}}$ & $240.60 \pm 2.81^{\mathrm{aA}}$ & $247.80 \pm 0.66^{\mathrm{bAB}}$ \\
\hline & & CONT & $255.73 \pm 4.02^{\mathrm{aB}}$ & $253.95 \pm 5.13^{\mathrm{bB}}$ & $252.59 \pm 3.24^{\mathrm{aB}}$ & $242.85 \pm 2.65^{\mathrm{aA}}$ & $245.43 \pm 1.55^{\mathrm{abA}}$ \\
\hline & \multirow{4}{*}{$\mathrm{Gl}$} & BOSO & $66.40 \pm 0.57^{\mathrm{aAB}}$ & $64.18 \pm 2.26^{\mathrm{aA}}$ & $67.31 \pm 0.20^{\mathrm{abB}}$ & $66.08 \pm 1.02^{\mathrm{aAB}}$ & $66.82 \pm 0.87^{\mathrm{aB}}$ \\
\hline & & $\mathrm{BO}$ & $66.29 \pm 1.02^{\mathrm{aA}}$ & $65.96 \pm 0.56^{\mathrm{abA}}$ & $67.19 \pm 0.54^{\mathrm{aA}}$ & $66.93 \pm 1.84^{\mathrm{abA}}$ & $70.34 \pm 1.28^{\mathrm{bB}}$ \\
\hline & & $\mathrm{SO}$ & $66.31 \pm 1.15^{\mathrm{aA}}$ & $67.38 \pm 0.68^{\mathrm{bA}}$ & $67.50 \pm 1.00^{\mathrm{abA}}$ & $65.82 \pm 0.71^{\mathrm{aA}}$ & $71.09 \pm 0.69^{\mathrm{bB}}$ \\
\hline & & CONT & $66.05 \pm 0.93^{\mathrm{aA}}$ & $67.45 \pm 1.08^{\mathrm{bAB}}$ & $68.71 \pm 1.02^{\mathrm{bB}}$ & $68.61 \pm 0.83^{\mathrm{bB}}$ & $70.88 \pm 0.39^{\mathrm{bC}}$ \\
\hline & \multirow{4}{*}{$\mathrm{Fr}$} & BOSO & $24.53 \pm 0.33^{\mathrm{bA}}$ & $24.09 \pm 0.73^{\mathrm{aA}}$ & $25.75 \pm 0.23^{\mathrm{aB}}$ & $25.40 \pm 0.37^{\mathrm{aB}}$ & $25.88 \pm 0.42^{\mathrm{aB}}$ \\
\hline & & $\mathrm{BO}$ & $23.64 \pm 0.37^{\mathrm{abA}}$ & $24.82 \pm 0.34^{\mathrm{aAB}}$ & $25.53 \pm 0.22^{\mathrm{aB}}$ & $25.76 \pm 0.70^{\mathrm{abB}}$ & $28.61 \pm 1.56^{\mathrm{bC}}$ \\
\hline & & $\mathrm{SO}$ & $23.65 \pm 0.63^{\mathrm{abA}}$ & $24.91 \pm 0.19^{\mathrm{aB}}$ & $25.35 \pm 0.36^{\mathrm{aB}}$ & $25.13 \pm 0.43^{\mathrm{aB}}$ & $29.39 \pm 0.39^{\mathrm{bC}}$ \\
\hline & & CONT & $23.13 \pm 0.60^{\mathrm{aA}}$ & $24.99 \pm 0.51^{\mathrm{aB}}$ & $25.95 \pm 0.46^{\mathrm{aBC}}$ & $27.51 \pm 1.70^{\mathrm{bCD}}$ & $28.47 \pm 0.29^{\mathrm{bD}}$ \\
\hline
\end{tabular}

\footnotetext{
${ }^{1)} \mathrm{BOSO}$, sauce with added preservatives and heated sterilization; BO, sauce with added preservatives; SO, heat sterilized sauce; CONT, unprocessed sauce.

${ }^{2)}$ Values are mean $\pm \mathrm{SD}$ of triplicate determinations.

${ }^{3)}$ Values followed by different uppercase letters $\left({ }^{\mathrm{a}-\mathrm{c}}\right)$ within a row and by different uppercase letters $\left({ }^{\mathrm{A}-\mathrm{D}}\right)$ within a column are significantly different at $\mathrm{p}<0.05$ based on Duncan's multiple range test.

${ }^{4)} \mathrm{Su}$, sucrose; Gl, glucose; Fr, fructose.
} 
것을 확인할 수 있었다. 샘플의 저장 기간에 따른 유의적 차이가 있는 것으로 보이지만, 전처리 방법 별 차이는 비 교적 크지 않았다. 종합해 볼 때 저장 초기 미생물 및 기타 물리적 변화에 의해 전반적으로 sucrose 함량이 감소하는 경향을 보이나 이후 비슷한 경향을 보이며, Kim과 Park (2010), Kwak 등(2002)의 연구에서도 유사한 분석결과를 확인할 수 있었다.

\section{색도}

소스의 색도 측정 결과는 Table 4에 나타냈다. 모든 시료 의 명도 $\left(\mathrm{L}^{*}\right)$ 값은 33.63-29.16 범위로 저장 기간에 따라 유의적으로 감소했으며, $\mathrm{CONT}$ 와 $\mathrm{BO}$ 가 비교적 가장 높은
값을 보였고, $\mathrm{SO}$ 와 $\mathrm{BOSO}$ 는 그에 비해 낮은 명도를 나타 났다. 하지만 처리구간 큰 차이는 없었다. 적색도 $\left(\mathrm{a}^{*}\right)$ 값은 또한 저장기간이 증가할수록 유의적으로 감소했으며, $\mathrm{CONT}$ 는 저장 6주 차를 제외하고 가장 높은 redness를 유 지했으며, $\mathrm{BOSO}$ 가 가장 낮은 경향이 나타났다. 황색도 $\left(b^{*}\right)$ 값에서는 저장 기간에 따라 유의적으로 감소했으며, 저장 중 시료에 따른 눈에 띄는 유의적 차이가 없었다. 색상 변화 정도를 나타내는 $\Delta \mathrm{E}$ 값은 모든 시료에서 저장 기간이 경과할수록 증가하는 경향을 보였으며, 저장 초기 에 $\Delta \mathrm{E}$ 값이 급증하였다가 그 값을 유지하였다. 따라서 고 추장 기반 떡볶이 소스가 저장 초기에 색상 변화가 심한 것을 확인할 수 있었다. $\mathrm{CONT}$ 와 $\mathrm{BO}$ 가 저장 6주 차까지

Table 4. Changes in color value of 'Tteokbokki' sauce during storage

\begin{tabular}{|c|c|c|c|c|c|}
\hline \multirow{2}{*}{ Color value ${ }^{1)}$} & \multirow{2}{*}{$\begin{array}{l}\text { Storage period } \\
\text { (week) }\end{array}$} & \multicolumn{4}{|c|}{ Sample ${ }^{2)}$} \\
\hline & & BOSO & $\mathrm{BO}$ & $\mathrm{SO}$ & CONT \\
\hline \multirow{5}{*}{$\mathrm{L}^{*}$} & 0 & $33.18 \pm 0.21^{3) \mathrm{aD} 4)}$ & $33.47 \pm 0.24^{\mathrm{bcC}}$ & $33.28 \pm 0.34^{\mathrm{abC}}$ & $33.63 \pm 0.23^{\mathrm{cD}}$ \\
\hline & 2 & $29.77 \pm 0.17^{\mathrm{aB}}$ & $30.06 \pm 0.31^{\mathrm{bB}}$ & $29.78 \pm 0.22^{\mathrm{aB}}$ & $30.08 \pm 0.28^{\mathrm{bC}}$ \\
\hline & 4 & $30.02 \pm 0.22^{\mathrm{aC}}$ & $30.03 \pm 0.38^{\mathrm{aB}}$ & $29.82 \pm 0.30^{\mathrm{aB}}$ & $29.97 \pm 0.22^{\mathrm{aC}}$ \\
\hline & 6 & $29.16 \pm 0.24^{\mathrm{aA}}$ & $29.43 \pm 0.21^{\mathrm{bA}}$ & $29.27 \pm 0.33^{\mathrm{abA}}$ & $29.43 \pm 0.24^{\mathrm{bA}}$ \\
\hline & 8 & $29.26 \pm 0.26^{\mathrm{aA}}$ & $29.55 \pm 0.17^{\mathrm{bcA}}$ & $29.41 \pm 0.42^{\mathrm{abA}}$ & $29.77 \pm 0.33^{\mathrm{cB}}$ \\
\hline \multirow{5}{*}{$a^{*}$} & 0 & $12.68 \pm 0.35^{\mathrm{aD}}$ & $13.26 \pm 0.32^{\mathrm{bC}}$ & $12.89 \pm 0.43^{\mathrm{aC}}$ & $13.28 \pm 0.36^{\mathrm{bC}}$ \\
\hline & 2 & $11.42 \pm 0.39^{\mathrm{aBC}}$ & $11.56 \pm 0.37^{\mathrm{abB}}$ & $11.39 \pm 0.22^{\mathrm{aAB}}$ & $11.76 \pm 0.55^{\mathrm{bB}}$ \\
\hline & 4 & $11.59 \pm 0.36^{\mathrm{abC}}$ & $11.43 \pm 0.52^{\mathrm{aAB}}$ & $11.64 \pm 0.33^{\mathrm{abB}}$ & $11.81 \pm 0.42^{\mathrm{bB}}$ \\
\hline & 6 & $11.19 \pm 0.44^{\mathrm{aB}}$ & $11.49 \pm 0.33^{\mathrm{aB}}$ & $11.24 \pm 0.40^{\mathrm{aA}}$ & $11.35 \pm 0.42^{\mathrm{aA}}$ \\
\hline & 8 & $10.80 \pm 0.29^{\mathrm{aA}}$ & $11.19 \pm 0.28^{\mathrm{bA}}$ & $11.16 \pm 0.44^{\mathrm{bA}}$ & $11.41 \pm 0.36^{\mathrm{bA}}$ \\
\hline \multirow{5}{*}{$b^{*}$} & 0 & $12.62 \pm 0.48^{\mathrm{aC}}$ & $12.99 \pm 0.46^{\mathrm{aB}}$ & $12.60 \pm 0.62^{\mathrm{aC}}$ & $12.98 \pm 0.41^{\mathrm{aD}}$ \\
\hline & 2 & $11.24 \pm 0.46^{\mathrm{aB}}$ & $11.42 \pm 0.44^{\mathrm{aA}}$ & $11.36 \pm 0.31^{\mathrm{aB}}$ & $11.70 \pm 0.31^{\mathrm{bC}}$ \\
\hline & 4 & $11.37 \pm 0.43^{\mathrm{aB}}$ & $11.29 \pm 0.65^{\mathrm{aA}}$ & $11.35 \pm 0.42^{\mathrm{aB}}$ & $11.48 \pm 0.49^{\mathrm{aBC}}$ \\
\hline & 6 & $10.87 \pm 0.43^{\mathrm{aA}}$ & $11.35 \pm 0.31^{\mathrm{bA}}$ & $10.96 \pm 0.39^{\mathrm{aA}}$ & $10.95 \pm 0.55^{\mathrm{aA}}$ \\
\hline & 8 & $10.65 \pm 0.31^{\mathrm{aA}}$ & $11.09 \pm 0.33^{\mathrm{bcA}}$ & $10.99 \pm 0.45^{\mathrm{bA}}$ & $11.29 \pm 0.37^{\mathrm{cB}}$ \\
\hline \multirow{5}{*}{$\Delta \mathrm{E}$} & 0 & $0.00 \pm 0.00^{\mathrm{aA}}$ & $0.00 \pm 0.00^{\mathrm{aA}}$ & $0.00 \pm 0.00^{\mathrm{aA}}$ & $0.00 \pm 0.00^{\mathrm{aA}}$ \\
\hline & 2 & $3.93 \pm 0.27^{\mathrm{aC}}$ & $4.14 \pm 0.42^{\mathrm{aB}}$ & $4.02 \pm 0.26^{\mathrm{aB}}$ & $4.12 \pm 0.21^{\mathrm{aB}}$ \\
\hline & 4 & $3.60 \pm 0.29^{\mathrm{aB}}$ & $4.32 \pm 0.38^{\mathrm{cB}}$ & $3.91 \pm 0.31^{\mathrm{bB}}$ & $4.25 \pm 0.39^{\mathrm{cB}}$ \\
\hline & 6 & $4.66 \pm 0.43^{\mathrm{aD}}$ & $4.71 \pm 0.31^{\mathrm{aC}}$ & $4.65 \pm 0.45^{\mathrm{aC}}$ & $5.09 \pm 0.37^{\mathrm{bD}}$ \\
\hline & 8 & $4.80 \pm 0.23^{\mathrm{bD}}$ & $4.84 \pm 0.17^{\mathrm{bC}}$ & $4.59 \pm 0.17^{\mathrm{aC}}$ & $4.64 \pm 0.22^{\mathrm{aC}}$ \\
\hline
\end{tabular}

${ }^{1)} \mathrm{L}^{*}$, lightness; $\mathrm{a}^{*}$, redness; $\mathrm{b} *$, yellowness.

${ }^{2}$ BOSO, sauce with added preservatives and heated sterilization; BO, sauce with added preservatives; SO, heat sterilized sauce; CONT, unprocessed sauce.

${ }^{3)}$ Values are mean \pm SD of triplicate determinations.

4) Values followed by different uppercase letters $\left({ }^{\mathrm{a}-\mathrm{c}}\right)$ within a row and by different uppercase letters $\left({ }^{\mathrm{A}-\mathrm{D}}\right)$ within a column are significantly different at $p<0.05$ based on Duncan's multiple range test. 
비교적 높은 값을 나타냈고, 저장 8 주 차에는 모든 시료의 $\Delta \mathrm{E}$ 값이 비슷해졌다. 이 결과는 고추장이 저장 기간에 따 라 $\mathrm{L}^{*}, \mathrm{a}^{*}, \mathrm{~b}^{*}$ 값은 감소하고, $\Delta \mathrm{E}$ 값은 증가하였다는 보고와 유사하였다(Kim과 Kwon, 2001). 고추장은 당과 아미노산 함량이 높아 Maillard 반응에 의한 변색에 기인함으로(Kim 과 Lee, 1994) 가열살균처리가 가장 크게 변색에 영향을 미쳐, 초기값이 CONT에 비해 낮은 것으로 사료된다. 또 한, 저장하는 동안 보존제 또한 변색에 영향을 준다는 것 을 알 수 있었다(Kim, 2007).

\section{미생물}

보존제 및 열처리 후 $35^{\circ} \mathrm{C}$ 에서 저장하는 동안 일반세균 과 효모 및 곰팡이 수를 변화를 측정한 결과는 Fig. 1에 나타냈다. 모든 샘플의 미생물 수는 처리 직후보다 감소하 는 추세를 보였다. 각각의 시료 초기 균수 값이 상당한 차이를 보이는 것은 각 처리구는 가열살균 및 보존제 첨가 후 병에 포장되었기 때문에, $\mathrm{BOSO}$ 와 $\mathrm{SO}$ 는 다른 처리구보 다 균이 비교적 많이 사멸된 후 포장되었을 것으로 보인 다. 저장 2 주 차부터는 모든 시료에서 미생물 수의 유의적 변화가 없이 비슷하게 유지되었다. 이는 소스의 미생물 대사에 의한 유기산 생성으로 $\mathrm{pH}$ 의 감소 및 적정 산도의 증가로 세균의 성장이 저해 받았기 때문이다 $(\mathrm{Kim}$ 등, 1993; Lee 등, 1997). BOSO는 저장 전반적으로 미생물 발 생이 가장 낮았으며, 다른 처리구들에 비하여 월등하게 미생물 수가 감소한 것을 확인하여, 보존제와 살균이 병용 되었을 때 각각 적용된 경우보다 훨씬 높은 미생물 억제 효과를 나타냄을 알 수 있었다. CONT는 처리구 중에서 가장 많은 미생물이 검출되었고, 전기간 동안 약 $5 \log$ $\mathrm{CFU} / \mathrm{g}$ 을 유지하였다. 소스에 첨가된 보존제 성분인 비타

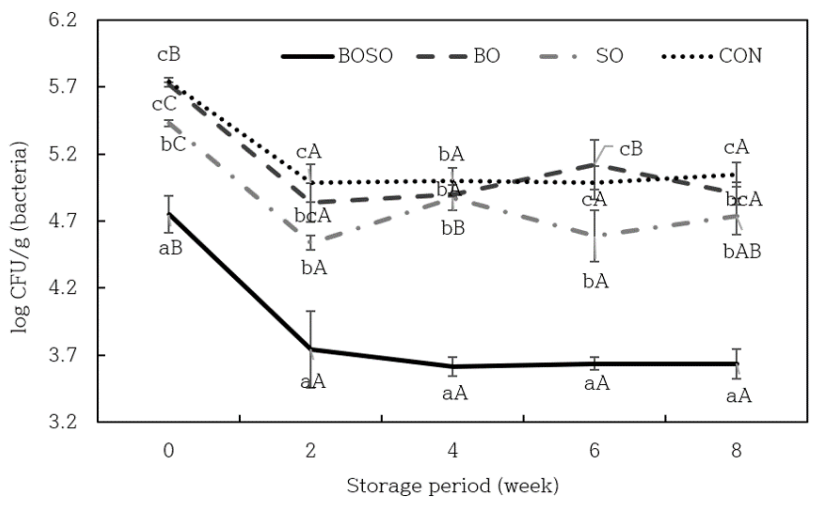

민 $\mathrm{B}_{1}$ 라우릴황산염은 곰팡이뿐만 아니라, 일반 세균에 대해 항균성을 가지고 있는 것으로 알려져 있지만(Kim, 2005), 가열살균 처리 없이 보존제만 첨가한 $\mathrm{BO}$ 는 CONT 과 유의적 차이가 없어, 보존제 단독으로 소스에 첨가되었 을 때는 미생물 억제에 큰 효과를 기대하기는 어려울 것으 로 보인다. 반면에, 가열살균 처리만 한 $\mathrm{SO}$ 는 $\mathrm{BO}$ 와 $\mathrm{CONT}$ 에 비해 미생물을 억제한 것을 확인하였지만, $\mathrm{BOSO}$ 의 수준에 미치는 수준은 아니었다. 저장기간 동안 세균과 곰팡이 및 효모 발생의 경향은 거의 유사하였다. 따라서 가열살균과 보존제의 병용처리는 각각 사용한 것보다 미 생물 억제 효과를 극대화하는 것을 확인하였다.

\section{관능검사}

저장 중 떡볶이 소스의 관능검사 결과는 Table 5 에 표기하 였다. 소스의 색은 $\mathrm{BO}$ 와 $\mathrm{SO}$ 가 저장 4주 차에만 색에 대한 기호도가 약간 감소하는 양상을 보였다. 앞서 colorimeter를 통한 색도 측정에서는 유의적인 차이를 보이는 구간도 있었 으나, 그 차이가 미미하여 관능검사 시에는 저장 기간 동안 모든 샘플에서 육안으로 차이를 확인할 수 없었다. 달콤한 향은 저장 4주 차에 CONT와 $\mathrm{SO}$ 에서 높은 점수를 받았으며, 점도는 저장 4주 차에 $\mathrm{SO}$ 가 높고, $\mathrm{BO}$ 가 낮은 것을 확인하였 다. 이 외에 신 향과 매운 향, 전반적 기호도는 모든 샘플에서 유사한 점수를 받았다. 따라서 열처리 살균이나 보존제 첨 가가 외관상, 풍미에 큰 변화를 주지 않아, 소비자들의 기호 도에 영향을 끼치지 않을 것으로 사료된다.

\section{요 약}

본 연구에서는 고추장을 바탕으로 한 떡볶이 소스에

Fig. 1. Changes in microorganisms of 'Tteokbokki' sauce during storage.

BOSO, sauce with added preservatives and heated sterilization; BO, sauce with added preservatives; SO, heat sterilized sauce; CONT, unprocessed sauce.

Values followed by different small letters $\left(^{\mathrm{a}-\mathrm{c}}\right)$ and by different capital letters $\left({ }^{\mathrm{A}, \mathrm{B}}\right)$ are significantly different at $\mathrm{p}<0.05$ based on Duncan's multiple range test according to the group and the storage period, respectively. 
Table 5. Changes in sensory qualities of 'Tteokbokki' sauce during storage

(unit: score)

\begin{tabular}{|c|c|c|c|c|c|c|}
\hline & \multirow{2}{*}{ Sample ${ }^{1)}$} & \multicolumn{5}{|c|}{ Storage period (week) } \\
\hline & & 0 & 2 & 4 & 6 & 8 \\
\hline \multirow{4}{*}{ Color } & BOSO & $6.50 \pm 0.71^{2) \mathrm{aB} 3}$ & $5.40 \pm 0.97^{\mathrm{aAB}}$ & $5.20 \pm 10.3^{\mathrm{aA}}$ & $5.70 \pm 1.57^{\mathrm{aAB}}$ & $5.30 \pm 1.49^{\mathrm{aA}}$ \\
\hline & $\mathrm{BO}$ & $6.50 \pm 0.53^{\mathrm{aB}}$ & $5.50 \pm 1.18^{\mathrm{aAB}}$ & $4.90 \pm 1.45^{\mathrm{aA}}$ & $5.80 \pm 1.14^{\mathrm{aAB}}$ & $5.30 \pm 1.42^{\mathrm{aA}}$ \\
\hline & $\mathrm{SO}$ & $6.40 \pm 0.70^{\mathrm{aB}}$ & $5.30 \pm 1.06^{\mathrm{aAB}}$ & $4.60 \pm 1.71^{\mathrm{aA}}$ & $5.40 \pm 1.65^{\mathrm{aAB}}$ & $5.00 \pm 1.49^{\mathrm{aA}}$ \\
\hline & CONT & $6.60 \pm 0.52^{\mathrm{aB}}$ & $5.30 \pm 1.42^{\mathrm{aA}}$ & $5.40 \pm 1.07^{\mathrm{aA}}$ & $6.20 \pm 1.03^{\mathrm{aAB}}$ & $5.50 \pm 1.27^{\mathrm{aA}}$ \\
\hline \multirow{4}{*}{$\begin{array}{l}\text { Sweet } \\
\text { flavor }\end{array}$} & BOSO & $4.90 \pm 1.60^{\mathrm{aB}}$ & $4.40 \pm 1.58^{\mathrm{aAB}}$ & $3.00 \pm 1.25^{\mathrm{aA}}$ & $4.40 \pm 1.65^{\mathrm{aAB}}$ & $3.90 \pm 1.60^{\mathrm{aAB}}$ \\
\hline & $\mathrm{BO}$ & $4.40 \pm 1.35^{\mathrm{aAB}}$ & $4.60 \pm 1.43^{\mathrm{aB}}$ & $3.10 \pm 0.88^{\mathrm{aA}}$ & $4.20 \pm 1.62^{\mathrm{aAB}}$ & $4.30 \pm 1.57^{\mathrm{aAB}}$ \\
\hline & SO & $4.70 \pm 1.57^{\mathrm{aA}}$ & $4.50 \pm 1.78^{\mathrm{aA}}$ & $4.50 \pm 0.85^{\mathrm{bA}}$ & $4.40 \pm 1.26^{\mathrm{aA}}$ & $4.00 \pm 1.33^{\mathrm{aA}}$ \\
\hline & CONT & $4.60 \pm 1.07^{\mathrm{aA}}$ & $4.90 \pm 1.85^{\mathrm{aA}}$ & $4.20 \pm 1.48^{\mathrm{bA}}$ & $4.30 \pm 1.25^{\mathrm{aA}}$ & $4.00 \pm 1.56^{\mathrm{aA}}$ \\
\hline \multirow{4}{*}{$\begin{array}{l}\text { Sour } \\
\text { flavor }\end{array}$} & BOSO & $3.10 \pm 0.99^{\mathrm{aA}}$ & $3.50 \pm 1.35^{\mathrm{aA}}$ & $3.80 \pm 1.32^{\mathrm{aA}}$ & $3.10 \pm 1.37^{\mathrm{aA}}$ & $3.30 \pm 1.34^{\mathrm{aA}}$ \\
\hline & $\mathrm{BO}$ & $4.00 \pm 1.63^{\mathrm{aA}}$ & $3.20 \pm 1.48^{\mathrm{aA}}$ & $3.60 \pm 1.51^{\mathrm{aA}}$ & $2.90 \pm 1.20^{\mathrm{aA}}$ & $4.20 \pm 1.48^{\mathrm{aA}}$ \\
\hline & $\mathrm{SO}$ & $4.00 \pm 1.63^{\mathrm{aA}}$ & $3.20 \pm 1.03^{\mathrm{aA}}$ & $3.60 \pm 1.26^{\mathrm{aA}}$ & $3.00 \pm 1.41^{\mathrm{aA}}$ & $3.80 \pm 1.75^{\mathrm{aA}}$ \\
\hline & CONT & $3.50 \pm 1.84^{\mathrm{aA}}$ & $3.70 \pm 1.70^{\mathrm{aA}}$ & $3.90 \pm 1.73^{\mathrm{aA}}$ & $3.30 \pm 1.57^{\mathrm{aA}}$ & $3.40 \pm 1.43^{\mathrm{aA}}$ \\
\hline \multirow{4}{*}{$\begin{array}{l}\text { Spicy } \\
\text { flavor }\end{array}$} & BOSO & $3.00 \pm 1.33^{\mathrm{aA}}$ & $4.10 \pm 1.79^{\mathrm{aA}}$ & $3.90 \pm 1.20^{\mathrm{aA}}$ & $3.20 \pm .123^{\mathrm{aA}}$ & $3.30 \pm 1.49^{\mathrm{aA}}$ \\
\hline & $\mathrm{BO}$ & $3.30 \pm 1.70^{\mathrm{aA}}$ & $3.80 \pm 1.62^{\mathrm{aA}}$ & $3.30 \pm 0.95^{\mathrm{aA}}$ & $3.40 \pm 1.65^{\mathrm{aA}}$ & $3.20 \pm 1.87^{\mathrm{aA}}$ \\
\hline & SO & $3.30 \pm 1.77^{\mathrm{aA}}$ & $4.00 \pm 1.41^{\mathrm{aA}}$ & $3.30 \pm 1.16^{\mathrm{aA}}$ & $2.90 \pm 1.45^{\mathrm{aA}}$ & $3.60 \pm 1.90^{\mathrm{aA}}$ \\
\hline & CONT & $3.20 \pm 1.75^{\mathrm{aA}}$ & $3.90 \pm 1.37^{\mathrm{aA}}$ & $3.30 \pm 1.25^{\mathrm{aA}}$ & $3.30 \pm 1.64^{\mathrm{aA}}$ & $3.40 \pm 1.58^{\mathrm{aA}}$ \\
\hline \multirow{4}{*}{ Viscosity } & BOSO & $5.20 \pm 0.92^{\mathrm{aB}}$ & $5.30 \pm 0.82^{\mathrm{aB}}$ & $4.40 \pm 1.17^{\mathrm{abAB}}$ & $4.20 \pm 1.40^{\mathrm{aAB}}$ & $3.70 \pm 1.25^{\mathrm{aA}}$ \\
\hline & $\mathrm{BO}$ & $4.90 \pm 1.10^{\mathrm{aB}}$ & $4.90 \pm 0.88^{\mathrm{aB}}$ & $3.40 \pm 1.65^{\mathrm{aA}}$ & $3.60 \pm 1.35^{\mathrm{aA}}$ & $3.30 \pm 1.16^{\mathrm{aA}}$ \\
\hline & SO & $5.30 \pm 0.95^{\mathrm{aB}}$ & $5.20 \pm 0.92^{\mathrm{aB}}$ & $4.80 \pm 0.92^{\mathrm{bAB}}$ & $4.00 \pm 0.82^{\mathrm{aA}}$ & $4.20 \pm 1.48^{\mathrm{aA}}$ \\
\hline & CONT & $4.40 \pm 1.35^{\mathrm{aAB}}$ & $5.10 \pm 1.29^{\mathrm{aB}}$ & $4.30 \pm 0.82^{\mathrm{abAB}}$ & $3.90 \pm 0.88^{\mathrm{aA}}$ & $3.50 \pm 1.27^{\mathrm{aA}}$ \\
\hline \multirow{4}{*}{$\begin{array}{c}\text { Overall } \\
\text { acceptability }\end{array}$} & BOSO & $5.60 \pm 0.52^{\mathrm{aB}}$ & $5.30 \pm 0.82^{\mathrm{aB}}$ & $4.90 \pm 0.99^{\mathrm{aAB}}$ & $4.80 \pm 1.69^{\mathrm{aAB}}$ & $4.20 \pm 1.14^{\mathrm{aA}}$ \\
\hline & $\mathrm{BO}$ & $6.00 \pm 0.94^{\mathrm{aC}}$ & $5.50 \pm 1.08^{\mathrm{aBC}}$ & $4.30 \pm 1.25^{\mathrm{aA}}$ & $5.00 \pm 1.05^{\mathrm{aABC}}$ & $4.60 \pm 1.17^{\mathrm{aAB}}$ \\
\hline & SO & $5.50 \pm 0.71^{\mathrm{aA}}$ & $5.20 \pm 0.92^{\mathrm{aA}}$ & $5.00 \pm 1.25^{\mathrm{aA}}$ & $4.70 \pm 1.64^{\mathrm{aA}}$ & $4.80 \pm 1.69^{\mathrm{aA}}$ \\
\hline & CONT & $5.60 \pm 0.84^{\mathrm{aA}}$ & $5.10 \pm 1.29^{\mathrm{aA}}$ & $4.60 \pm 1.84^{\mathrm{aA}}$ & $5.20 \pm 1.81^{\mathrm{aA}}$ & $4.70 \pm 1.49^{\mathrm{aA}}$ \\
\hline
\end{tabular}

${ }^{1)} \mathrm{BOSO}$, sauce with added preservatives and heated sterilization; BO, sauce with added preservatives; SO, heat sterilized sauce; CONT, unprocessed sauce.

${ }^{2)}$ Values are mean $\pm \mathrm{SD}$ of triplicate determinations.

${ }^{3)}$ Values followed by different uppercase letters $\left({ }^{\mathrm{a}, \mathrm{b}}\right)$ within a row and by different uppercase letters $\left({ }^{\mathrm{A}-\mathrm{C}}\right)$ within a column are significantly different at $\mathrm{p}<0.05$ based on Duncan's multiple range test.

보존제 및 가열살균처리를 각각 처리 및 병용 처리하여, 그 효과를 비교하였다. 보존제 및 가열 살균 병용 처리를 한 경우, $\mathrm{CO}_{2}$ 가스 발생이 증가하였으며, 보존제와 가열 살균만 실행한 경우에는 가스 발생이 대조구에 비하여 감소하였다. 염도, 가용성 고형분 및 $\mathrm{pH}$ 는 처리구 간에 유의적인 차이는 발생하지 않았다. 소스의 단맛을 결정짓 는 환원당과 유리당 함량은 병용 처리 시 감소하였으며,
다른 처리구는 대조구와 비슷하였다. 소스의 명도와 적색 도는 가열살균처리가 된 샘플들이 대조구에 비해 낮은 값을 보였으나, 심한 변색을 일으키지는 않았다. 미생물 발생량은 병용 처리된 샘플이 현저하게 낮았으며, 살균 처리만 된 처리구도 미미하게 살균효과가 있었다. 하지만 보존제만 첨가된 처리구는 대조구에 비해 효과가 전혀 나타나지 않아, 소스의 살균을 위해서 보존제 첨가만으로 
는 부족할 것으로 보인다. 관능검사 결과, 다양한 향과 외관 면에서 처리구간 차이가 나타나지 않았다. 따라서 떡볶이 소스에서 가열 살균은 대조구에 비해 살균 효과가 나타났으며, 보존제와 병용 처리될 시 그 살균효과가 극대 화될 것으로 보인다. 보존제만 처리했을 경우, 소스의 품 질을 향상시킬 만한 결과는 없었다. 하지만 병용 처리 시 반드시 열에 안정한 보존제를 사용하여, 이산화탄소 가스 발생을 방지하여야 할 것으로 사료된다.

\section{감사의 글}

본 연구는 농림축산식품부 농식품수출비지니스전략모 델구축사업의 의성마늘을 이용한 중국 수출용 고부가가 치 소스 개발 과제(319087-03-1-CG000)에 의해 이루어진 것임.

\section{Conflict of interests}

The authors declare no potential conflict of interest.

\section{ORCID}

Ji-Young Choi https://orcid.org/0000-0002-7854-9277 Kwang-Deog Moon

https://orcid.org/0000-0001-5277-3345

\section{References}

Cho NC, Jhon DY, Shin MS, Hong YH, Lim HS. Effect of garlic concentrations on growth of microorganisms during kimchi fermentation. Korean J Food Sci Tech, 20, 231-235 (1988)

Choi JB, Cho WI, Jung JY, Chung MS. Sterilization of Gochujang sauce with continuous ohmic heating. Korean J Food Sci Technol, 47, 474-479 (2015)

Choi YH, Shim YS, Kim CT, Lee C, Shin DB. Characteristics of thiosulfinates and volatile sulfur compounds from blanched garlic reacted with alliinase. Korean J Food Sci Technol, 39, 600-607 (2007)

Chun MS, Lee TS, Noh BS. The changes in organic acids and fatty acids in Kochujang prepared with different mashing methods. Korean J Food Sci Technol, 27, 25-29 (1995)

Ghose TK. Measurement of cellulose activities. Pure Appl Chem, 59, 257-268 (1987)

Hong SP, Shin DB, Cho GH. Development of new sauce products using traditional Gochujang. Food Science and Industry, 41, 96-101 (2008)

Kang MK, Song KB. Quality characterstics of Gochujang with the addition of skipjack cooking broth as protein source. Korean J Food Preserv, 13, 457-464 (2006)

Kim BS, Yang SB. Heat effects for the volatile organic compounds emitted from garlic and kimchee. J Korean Environ Sci Soc, 7, 615-622 (1998)

Kim DH, Yook HS, Youn KC, Sohn CB, Byun MW. Changes of microbiological and general quality characteristics of gamma irradiated Kochujang (fermented hot pepper paste). Korean J Food Sci Technol, 33, $72-77$ (2001)

Kim DH, Lee JS, Lee SB. Effect of storage conditions on the chemical characteristics of traditional Kocujang. Korean J Food Sci Technol, 34, 466-471 (2002)

Kim DH, Kwon YM. Effect of storage conditions on the microbiological and physicochemical characteristics of traditional Kochujang. Korean J Food Sci Technol, 33, 589-595 (2001)

Kim MS, Oh JA, Kim IW, Shin DH, Han MS. Fermentation properties of irradiated Kochujang. Korean J Food Sci Technol, 30, 934-940 (1998)

Kim KB, Kim HA, Choi SK. Sensory characterisitics of soybean paste (Doenjang) Tteokbokki sauce with Chines sauce. Foodservice Industry Journal, 43-59 (2011)

Kim GT, Hwang YI, Lim SI, Lee DS. Carbon dioxide production and quality changes in Korean fermented soybean paste and hot pepper-soybean paste. Korean Soc Food Sci Nutr, 29, 807-813 (2000)

Kim JO, Lee KH. Effect of temperature on color and color-preference of industry-produced Kochujang during storage. J Korean Soc Food Nutr, 23, 641-646 (1994)

Kim IS. A study on the consumers' use of processed food of Prunus mume and development of processed food. MS Thesis, Yeungnam University, Korea, p 59-73 (2007)

Kim HD. The proximate composition, free sugars contents and sensory characteristics of demi-glace sauce according to the varying quantity of Omija added. J East Asian Soc Dietary Life, 14, 598-607 (2004)

Kim YS, Park GS. Quality characteristics of Gochujang sauce with concentrated Salicornia herbacea L. extracts. J East Asian Soc Dietary Life, 20, 939-946 (2010)

Kim YS, Shin DB, Jeong MC, Oh HI, Kang TS. Changes in quality characteristics of traditional Kochujang during fermentation. Korean J Food Sci Technol, 25, 724-729 (1993) 
Kim YS, Kwon DJ, Koo MS, Oh HI, Kang TS. Changes in microflora and enzyme activities of traditional Kochujang during fermentation. Korean J Food Sci Technol, 25, 502-509 (1993)

Kim JI. Compositions for sterilization and preservation of food. Korea Patent No. 10-2005-0105876 (2005)

Kim DH, Youn KS, Kim SD. Effect of kimchi materials on the gas formation and vessel pressure during storage. Korean J Food Preserv, 9, 144-147 (2002)

Kwak EJ, An JH, Lee HG, Shin MJ, Lee YS. A study on physicochemical characteristics and sensory evaluation according to development of herbal sauces of Jujube and Omija. J Korean Soc Food Sci Nutr, 31, 7-11 (2002)

Kwon HS. Changes in physicochemical properties and microorganisms during the storage of kimchi stew's sauce. J Korean Soc Food Sci Nutr, 28, 107-112 (1999)

Lee NH, Jo EJ, Oh SW, Hong SP. Study on the hurdle technique for the reduction of Bacillus cereus spores in Doenjang and Gochujang. J Korean Soc Food Sci Nutr, 41, 1842-1846 (2012a)

Lee KY, Kim HS, Lee HG, Han O, Chang UJ. Studies on the prediction of the shelf-life of Kochujang through the physicochemical and sensory analyses during storage. J Korean Soc Food Sci Nutr, 26, 588-594 (1997)

Lee JH, Kim ML, Min HS, Lee YY, Song YS, Kwon SJ, Kim MJ, Song MN. The Food \& Principle of Cookery.
Kyomunsa Publishing Co, Paju, Korea, p 71, 130-140 (2012b)

Lee JS, Kwon SJ, Chung SW, Choi YJ, Yoo JY, Chung $\mathrm{DH}$. Changes of microorganisms, enzyme activities and major components during the fermentation of Korean traditional Doenjang and Kochujang. Kor J Appl Microbial Biotechnol, 24, 247-253 (1996)

Lee SY, Jeong HJ, Lee YY, Kim ML, Kim ML(b), Song HN. Food chemistry. Powerbook Publishing Co, Seoul, Korea, p 355-357 (2013)

Li XQ, Zhang F, Sun YY, Yong W, Chu XG, Fang YY, Zweigenbaum J. Accurate screening for synthetic preservatives in beverage using high performance liquid chromatography with time-off-flight mass spectrometry. Anal Chim Acta, 608, 165-177 (2008)

Mantis AJ, Karaioannoglou PG, Spanos GP, Panetsos AG. The effect of garlic extract on food poisoning bacteria in culture media. I. Staphylococcus aureus. Lebensm Wiss Technol, 11, 26-28 (1978)

Park YO. Physicochemical characteristics and storage stabilities of soy sauce and soybean paste sauce added with extracts of pear and sugar. Korean J Food Preserv, 22, 465-474 (2015)

Song HS, Kim YM, Lee KT. Antioxidant and anticancer activities of traditional Kochujang added with garlic porridge. J Life Sci, 18, 1140-1146 (2008) 